血小板電気泳動度とその生理的意義

菊谷 典 久* 本 宮 武 司* 榊 原 千枝子*
渡 辺 節 子* 山 崎 博 男*

\title{
Electrophoretic mobility of platelets and its physiological significance
}

\author{
Norihisa KIKUTANI*, Takeshi MOTOMIYA*, Chieko SAKAKIBARA*, \\ Setsuko WATANABE* and Hiroh YAMAZAKI*
}

Key words : electrophoresis of platelets, neuraminidase, platelet volume

Increasing attention has been paid to the surface electrical charge of platelets in relation to their functions. However there are several criticisms in methodological respects. In the present investigation the effect of neuraminidase on platelets was examined utilizing newly developed instruments of electrophoresis. These are Free-Flow Electrophoresis model Vap-5 (Bender and Hobein, West Germany) and Laser-Zee System 3000 (Pen-Kem Inc., U.S.A.). Rabbits were catheterized in the carotid artery and blood was obtained with EDTA as an anticoagulant. Platelet rich plasma was washed twice with Tris- $\mathrm{HCl}$ buffered saline and platelets were finally suspended in $\mathrm{pH} 5.3$ acetate buffered saline. Washed platelets added with various concentrations of neuraminidase or control saline were incubated at $37^{\circ} \mathrm{C}$ for an hour. After incubation platelets were washed and suspended in $3 \mathrm{mM}$ triethanolamine acetate or $0.001 \mathrm{M}$ HEPES$\mathrm{NaOH}, 0.15 \mathrm{M} \mathrm{NaCl}$ buffer for electrophoresis with Free-Flow or Laser-Zee system respectively.

Results: Electrophoretic distribution of neuraminidase-treated platelets was shifted to the cathode side as compared with the control. The magnitude in shift of electrophoretic distribution depended upon neuraminidase concentration and there was a correlation between them (Fig. 1A, B). Relation between electrophoretic mobility and volume of platelets before and after the neuraminidase treatment was shown in Fig. 2A, B and 3. In general larger platelets were distributed in the anode side and smallers in the cathode side. With lower concentration of neuraminidase treatment this trend as shown by a regression line got greater. This result represents that the sensitivity of platelets to neuraminidase is various in accordance with the platelet volume and smaller platelets are more sensitive to neuraminidase. The platelet sensitivity to neuraminidase

* 東京都臨床医学総合研究所循環器部〔干113 東京都文京区本駒込3-18-22〕, Division of Cardiovascular Research, The Tokyo Metropolitan Institute of Medical Science, Tokyo, Japan, 
may have some role in platelet turn-over as smaller platelets have been believed as older ones.

\section{緒言}

細胞電気泳動の血小板への応用は，1960年代 を中心に数多くなされてきている11. 1968 年 Bolton ら ${ }^{2)}$ は，「冠動脈疾患患者の血小板の泳 動度は，健常者に比し,大きい」と報告.また， 1969 年 Gröttum ら ${ }^{3)}$ は「Congenital Macrothrombocytic Thrombocytopenia では, その血 小板の泳動度は低下している」と報告してい る. とのように血小板の電気泳動度と，その機 能・形態との間には密接な関係があるととが示 されているが，現在の電気泳動法には，いくつ かの欠点がある．たとえば，(1)計時操作に由来 する誤差，(2)手動のために測定細胞数の増加に は限度があること，(3)泳動度に応じて血小板を 分離・採取できないとと，などである。そこで われわれは，本来 lysosomes など細胞内小器 官の分離・採取を目的に近年開発された Hannig 考案) の無担体連続電気泳動装置 (Bender \& Hobein GMBH) および米国 Pen-Kem 社 で開発された自動化泳動装置 Laser-Zee System 3000 を血小板に用い, neuraminidase の血小 板に対する影響を調べ, 多少の知見が得られた ので報告する。

\section{I. 実験方法}

体重 2.5 3.5kg の成熟家兔をペントバルビ タール麻醉下, 頸動脈にカニューレを挿入し EDTA 採血. 遠沈し PRP を得た後 Tris- $\mathrm{HCl}$ 緩衝生食水 $(\mathrm{pH} 7.4)$ にて 2 回洗浄し, 最後に 酢酸緩衝生食水 ( $\mathrm{pH}$ 5.3) 飞血小板を浮遊. 乙 の液に, Neuraminidase (西独 Behringwerke) および $\mathrm{CaCl}_{2}$ (終濃度 $12.5 \mathrm{mM}$ ) を加え, $37^{\circ} \mathrm{C}$ 1 時間インキュベート。なお， Neuraminidase のかわりに等容量の生食水を加え，同様に処理 したものを対照として用いた.インキュベート 後, 各電気泳動用緩衝液*で洗浄, 浮遊し, 泳 動を行った.

（*無担体連続電気泳動用緩衝液：0.25M Suc- rose, 1mM EDTA を含む $3 \mathrm{mM}$ トリエタノ ールアミン酢酸溶液, $\mathrm{pH}$ 7.4. Laser-Zee 用緩 衝液: 0.001M HEPES- $\mathrm{NaOH}, 0.15 \mathrm{M} \mathrm{NaCl}$ 溶液. $\mathrm{pH}$ 7.0).

〔使用機器〕無担体連続電気泳動装置 : 2 枚 のガラス板からなる分離槽の上部より，サンプ ルは注入され，左右両側に置かれた電極により 生じた電場中を落下していく，その落下中に荷 電粒子は，それぞれ陰または陽極に偏向してい く、下部には90本の採取フラクションがあり， Fr. 1 は陽極側, Fr. 90 は陰極側である. Laser-Zee System 3000 : 従来, 細胞の電極間 移動速度を顕微鏡などを利用し，直視下用手的 に測定していた部分を，レーザー光の散乱に置 きかえ，そのドップラー効果を利用して自動的 に泳動度を出す。それゆえ, 短時間に多くのサ ンプルが測定できる。

血小板数および容積は, Couter Counter ZBI および同 Channelyzer にて測定.

\section{II. 結 果}

Neuraminidase 活性 と血小板 電気泳動度変 化：血小板に作用させる neuraminidase 活性 を種々に変えて無担体連続電気泳動装置を使用 し, 酸素処理血小板と対照血小板の泳動度変化 をみた. 図 1- $\mathbf{A}$ は, 血小板 $2 \times 10^{8}$ あたり6.5U の酵素を作用させた場合で, 酵素処理群では対 照に比し, 全体に陰極側に分布が移動してい る. mode分画の差は 12 分画あった. また， 1.7 [U $/ 2 \times 10^{8}$ 血小板 $]$ では, 酵素処理と対照との mode 分画の差は 0 であったが, $2.5 \mathrm{U}$ で 3 分 画, $3.3 \mathrm{U}$ で 7 分画, $4.6 \mathrm{U}$ で10分画, $6.3 \mathrm{U}$ で 11分画となり，酵素濃度依存性の変化を示した (図 1-B).

血小板容積と電気泳動度 : 無担体連続電気泳 動装置により，各分画に分離された neuraminidase 処理扝よびその対照血小板について，そ の容積を測定し，分画番号と容積との関係をみ たのが図 2-A，Bである．Aは neuraminidase 


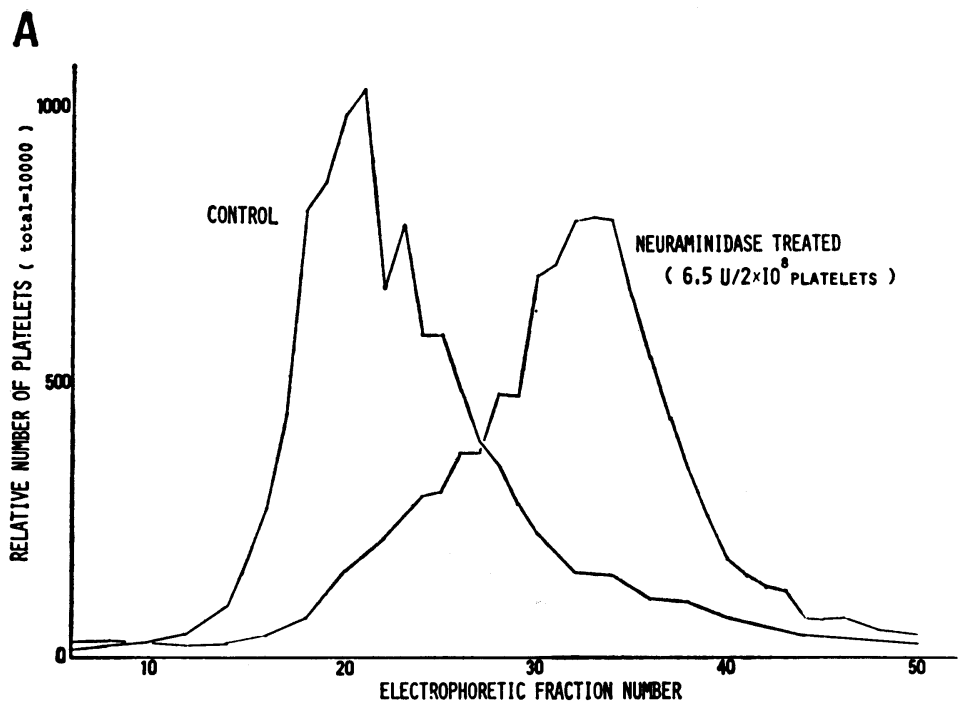

B

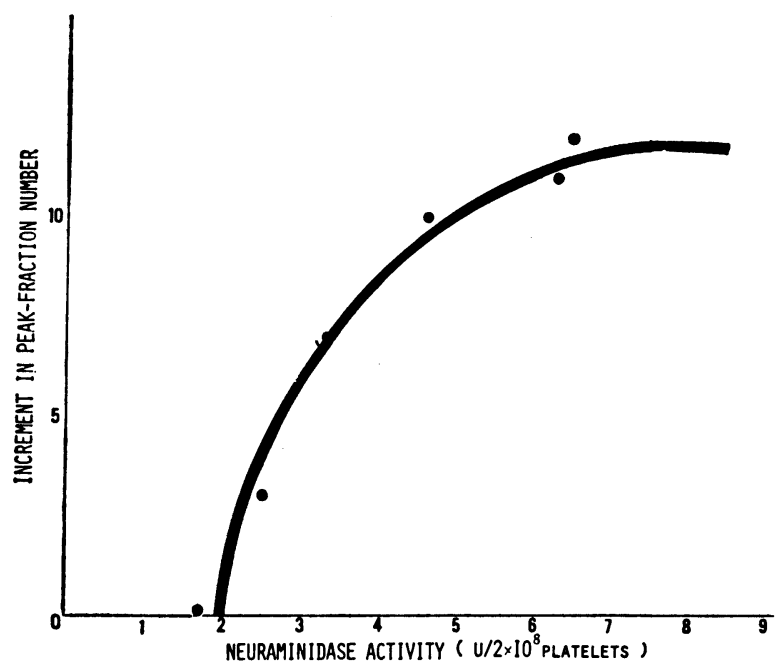

Fig. 1 A Electrophoretic mobility distribution of the control and neuraminidase treated platelets. The distribution of neuraminidase treated platelets is shifted to the cathode side as compared with the control.

B Relation between neuraminidase activity and the increment in the peak electrophoretic fraction number. The magnitude in shift of the peak fraction number depends upon neuraminidase activity.

活性を高くした場合の一例で，Bは低い場合で ある.なお，図に加えられた直線は，おのおの の回帰直線である.Aでは回帰直線の傾きは, ほぼ等しく, 酵素処理前後で, 各泳動分画での
容積分布様相にほとんど変化のないととを示唆 している. やや右下がりの直線は, 陰性荷電の 強い血小板の方がわずかに容積の大きいととを 示す.一方, Bでは, 対照に比し neuraminidase 
A

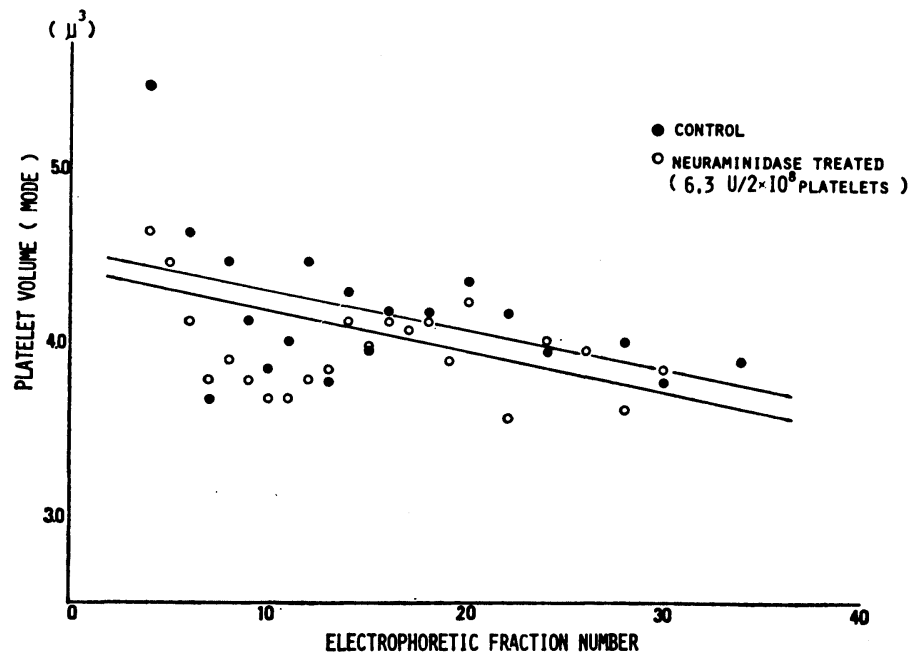

B

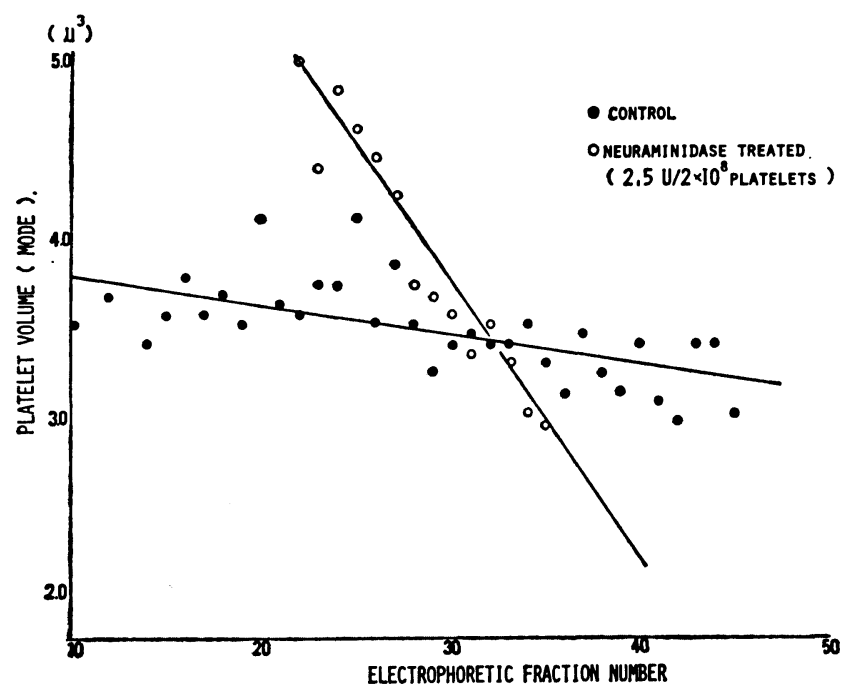

Fig. 2 Relation between electrophoretic mobility and platelet volume.

A : Neuraminidase concentration of 6.3 unit per $2 \times 18^{8}$ platelets. The slope of the regression line of neuraminidase treated platelets is almost as same is that of the control.

B : Neuraminidase concentration of 2.5 unit per $2 \times 10^{8}$ platelets. The slope of the regression line of neuraminidase treated platelets is steeper than that of the control.
と使用 neuraminidase 活 性をプロットしたものであ る. このグラフから, 酵素 活性の低い場合ほど傾きが 大きくなっていることがわ かる.な扔，酵素処理前後 では，全血小板の容積分布 には有意の変化は認められ なかった。

Laser-Zee System 3000 : 本機に打いても neuraminidase 処理血小板では，泳 動度が低下していることが mobility histogram に示さ れた。

\section{III. 考案および総括}

本宮ら5)はすでに抗ウサ ギ血小板モルモット血清を 使用し，家兔で作製した血 小板減少回復期の「若年血 小板」と仮定した血小板群 と，正常血小板群を無担体 連続電気泳動装置にかける と，「若年血小板」は正常 のあのに比し陰極側に分布 が移動するととを報告し た.この際，この結果が果 たして, 血小板の陰性荷電 の変化によるものなのか, それともこの装置の原理よ りみて，血小板容積および 比重が結果に影響している のではないかという疑問が 残った. 今回の neuraminidase 処理実験において, 使用した neuraminidase 活性と泳動分布のシフトの
処理血小板では回帰直線の傾きは著しく大きく なっており，陽極側の分画には大型血小板が,陰 極側には小型とほぼ順序よく分布し，血小板容 積により血小板泳動度の再分布が生じたととを 示唆している. 図了は，乙れら回帰直線の傾き
大きさには dose-dependent の関係が示され， 無担体連続電気泳動法は血小板の表面荷電の差 によって，それらを分離していることが示され た.

低活性の neuraminidase を血小板に 作用さ 
せると各分画の血小板容積 の分布様式が変化し，大型 ほど陽極側に分布し小型の あのほど陰極側に集まっ た。な扮， neuraminidase 処理によっては, 血小板の 容積そのものは変化しない ことから，血小板表面に存 在するシアル酸の neuraminidase に対する感受性 は血小板容積によって違っ ており，小型のものほど高 く, 酵素活性の低い場合に は小型血小板の シアル 酸 が，ほぼ選択的に外される ために，その陰性荷電が減 少して陰極側にシフトする 之考えられる. 一方, 酵素 活性が高くなると, どの血 小板む一様に一定レベルま

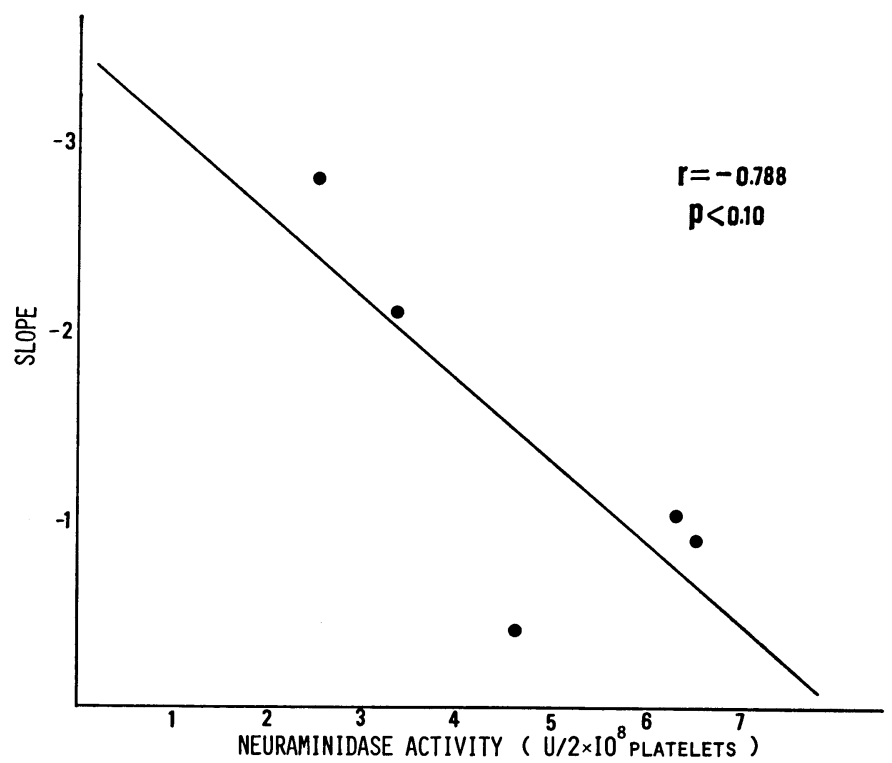

Fig. 3 Relation between neuraminidase activity and the slope of the regression line. There is reversed linear correlation between neuraminidase activity and the slope of the regression line.
でシアル酸が外されてしまうために，その容積 分布は対照と差がなくなってしまうと考えられ る. 従来老年血小板は小型で若年血小板は大型 であると考えられているが6)，上記のごとく， 小型血小板ほどシアル酸の neuraminidase に よる遊離性が高いとすると, 血小板回転のメカ ニズムに関して重要な示唆を与えると思われ る.

最後に，無担体連続電気泳動に関し，御指導いた だいた東京医科歯科大学遺伝生化学教室・中島 熙, 沢崎嘉男両氏に感謝する。

\section{文献}

1) Hampton, J.R., Mitchell, J.R.A.: Effect of aggregating agents on the electrophoretic mobility of human platelets. Br. Med. J., 1; 1074 1077, 1966.

2) Bolton, C.H., Hampton, J.R., Mitchell, J.
R.A.: Effect of oral contraceptive agents on platelets and plasma-phospholipids. Lancet, 1 ; 1336 1341, 1968.

3) Gröttum, K. A., Solum, N. O. : Congenital thrombocytopenia with giant platelets: a defect in the platelet membrane. Br. J. Haematol., 16; 277 290, 1969.

4) Hannig, K. : Eine Neuentwicklung der trägerfrein, kontinuierlichen Elektrophorese. Z. Physiol. Chem., 338; 211 227, 1964.

5）本宮武司，他：血小板年齢と容積，電気泳動 度の関係. 日血会誌， 41；2，397，1978.

6) Karpatkin, S.: Heterogeneity of human platelets. I. Metabolic and kinetic evidence suggestive of young and old platelets. J. Clin. Invest., 48; 1073 1082, 1969. 